\title{
CORTISONE TREATMENT OF NEPHROSIS
}

\author{
BY \\ GAVIN C. ARNEIL and H. ELLIS C. WILSON \\ From the Department of Child Health, University of Glasgow, and the Royal Hospital for Sick Children, Glasgow
}

(RECEIVED FOR PUBLICATION JUNE 17, 1952)

The accepted picture of the nephrotic syndrome is that of a grossly oedematous patient with massive albuminuria but having no hypertension or azotaemia. The amount of albumin circulating in the plasma is greatly reduced, resulting in a fall in the total protein content and a reversal of the albumin/ globulin ratio. The cholesterol content of the blood is markedly raised. Little is known of the aetiology of nephrosis itself, or of the spontaneous alterations which may occur in its manifestations. The oedema and albuminuria, for example, may vary dramatically and unpredictably, and occasionally vanish completely to result in the cure of the patient. As regards the oedema, it is suggested that this is caused by a retention of sodium which may in turn be produced by overactivity of the salt-retaining hormones of the adrenal glands. That such a mechanism will produce oedema is known, and is exemplified by the oedema occurring when an excess of desoxycorticosterone acetate (D.O.C.A.) is administered to normal subjects or even to patients with Addison's disease where dehydration and an excessive sodium output characterize the untreated case. Levitt and Bader (1951) have shown that in the extracellular fluids both cortisone (17-hydroxy11-dehydrocorticosterone) and A.C.T.H. (adrenocorticotrophic hormone) have a sodium-retaining action most pronounced in the first few days of therapy. Furthermore, experimental albuminuria in animals is increased by either cortisone or A.C.T.H. and diminished by adrenalectomy (Addis, Marmorston, Goodman, Sellers and Smith, 1950). It may therefore be accepted that an excess of adrenal hormones contribute to oedema and albuminuria. It has been firmly established that, following an intensive course of either cortisone or A.C.T.H., there is a transient depression of endogenous cortisone production by the patient (Luetscher and Deming, 1950; Kendall, 1951; McIntosh and Holmes, 1951). Presuming that a similar response occurred in nephrotic patients following sudden withdrawal of cortisone or A.C.T.H. it seemed possible that a diuresis from loss of sodium and a lessening of the albuminuria might result. In order to test this hypothesis cortisone was administered to nephrotic patients. and observations made on the effects of its sudden withdrawal. Cortisone was preferred to A.C.T.H. because contamination of the latter with antidiuretic hormone of the posterior pituitary frequently occurs and would make alterations arising in the water balance of the patients difficult to interpret.

\section{Method of the Present Investigation}

Six cases of nephrosis admitted to the Royal Hospital for Sick Children, Glasgow, were chosen for study. All conformed to the following criteria: (1) persistent oedema with ascites; (2) albuminuria exceeding $12 \mathrm{~g}$. per litre; (3) reduction in serum protein content with reversal of albumin/globulin ratio; (4) a cholesterol content of more than 250 mg. per $100 \mathrm{ml}$. of plasma; (5) the body weight to be stationary or rising for 10 days before starting treatment; (6) the non-protein nitrogen content of the blood to be less than $40 \mathrm{mg}$. per $100 \mathrm{ml}$; (7) the systolic blood pressure to be less than $115 \mathrm{~mm}$. of mercury.

All six cases were treated with large doses of cortisone, the hormone being stopped abruptly to induce the maximal rebound effect. At the time of writing all the cases have been under observation for at least eight months after treatment. Two of the cases received second courses of the hormone, distinguished in the text and tables by an asterisk. One case responded by diuresis on both occasions (J.H. and J.H.*), the other responded on neither (F.M. and F.M.*). The following observations are therefore based on eight courses of cortisone given to six patients with nephrosis. The patients, whose ages varied from 17 months to 7 years, were confined to bed and received a diet which contained less than $0.5 \mathrm{~g}$. ( $22 \mathrm{~m} \mathrm{Eq}$.) of sodium per day for at least one week before and for several weeks after the period of study. The cortisone was given intramuscularly for a five-day period in doses varying from 100 to $300 \mathrm{mg}$. per day according to the expected weight of the patient, along with $2 \mathrm{~g}$. 
of potassium chloride daily by mouth. This dosage of cortisone resulted in a marked depression of the circulating eosinophils during seven of the eight courses, the exception being J.H.*. The patients were weighed each day and the urinary output of albumin measured by the Esbach method. In such young patients the collection of the total urinary output over the prolonged period of the investigation was considered impracticable and was not attempted. Samples of blood were withdrawn before, during and after the cortisone therapy. The total serum proteins were estimated on these occasions and fractionated by the electrophoretic technique suggested by Cremer and Tiselius (1950). The non-protein nitrogen and plasma cholesterol were also estimated. In four cases measurements of plasma volume and blood volume were made by the Evans blue (T1824) method for hyperlipaemic sera described by Chinard and Eder (1948).

\section{The Results of the Investigation}

The effects of cortisone on oedema, albuminuria, serum proteins and cholesterol are discussed under separate headings. The details of the case histories are given in the summaries appended.

Effects of Cortisone on Oedema. Alterations occurring in oedema are best judged by changes in the body weight. During the period of cortisone treatment there was some increase in the oedema on five of the eight occasions; in no case was the increase striking, the greatest gains in weight being in J.H. and F.M. whose weight increased by $1.1 \mathrm{~kg}$. each. It may be significant that in three of the four cases where the subsequent diuresis was most marked the weight during cortisone therapy either fell or remained unchanged.

On five occasions diuresis occurred within 12 days of stopping the cortisone; in some cases the diuresis was extreme, in J.N. amounting to $9 \cdot 2 \mathrm{~kg}$. or $32.3 \%$ of his original weight. In three instances where diuresis did not occur the weight continued to rise even after the cortisone was discontinued. Detailed information will be found in Table 1 where a five-day period 14 to 18 days after cortisone was chosen as that period at which the weights of the subjects were constantly lowest. In J.N., J.H. and J.H.* the oedema returned after 67,17 and 78 days respectively: in R.P. and A.P. it has not recurred after nine months.

Effects of Cortisone on Albuminuria. In all cases the albuminuria increased during cortisone therapy and fell below the original level after the hormone was stopped. That this reduction was due to decreased daily loss of protein and not to dilution of the urine caused by water diuresis can be accepted, since the Esbach reading fell from over 16 parts
TABLE 1

BODY WEIGHT BEFORE, DURING AND AFTER CORTISONE TREATMENT

\begin{tabular}{|c|c|c|c|c|c|}
\hline Case & $\begin{array}{c}\text { Mean } \\
\text { Weight } \\
\text { (kg.) for } \\
5 \text { Days } \\
\text { preceding } \\
\text { Cortisone } \\
\text { Treatment }\end{array}$ & $\begin{array}{c}\text { Mean } \\
\text { Weight } \\
\text { (kg.) for } \\
5 \text { Days } \\
\text { during } \\
\text { Cortisone } \\
\text { Treatment }\end{array}$ & $\begin{array}{c}\text { Mean } \\
\text { Weight } \\
\text { (kg.) for } \\
\text { 14-18 Days } \\
\text { after } \\
\text { Cortisone } \\
\text { Treatment }\end{array}$ & $\begin{array}{l}\text { Gain or } \\
\text { Loss in } \\
\text { Weight } \\
\text { as \% of } \\
\text { Original } \\
\text { Weight }\end{array}$ & $\begin{array}{l}\text { No. of Days } \\
\text { between End } \\
\text { of Cortisone } \\
\text { and Onset } \\
\text { of Diuresis }\end{array}$ \\
\hline $\begin{array}{l}\text { R.P. } \\
\text { A.P. } \\
\text { J.N. } \\
\text { J.H. } \\
\text { J.H.** } \\
\text { C.Y. } \\
\text { F.M. } \\
\text { F.M.* }\end{array}$ & $\begin{array}{l}13 \cdot 8 \\
13 \cdot 2 \\
28 \cdot 5 \\
18 \cdot 2 \\
14 \cdot 6 \\
23 \cdot 2 \\
27 \cdot 5 \\
20 \cdot 8\end{array}$ & $\begin{array}{l}13 \cdot 5 \\
13 \cdot 2 \\
28 \cdot 3 \\
19 \cdot 3 \\
15 \cdot 4 \\
23 \cdot 5 \\
28 \cdot 6 \\
21 \cdot 4\end{array}$ & $\begin{array}{l}11 \cdot 1 \\
10 \cdot 6 \\
19 \cdot 3 \\
13 \cdot 9 \\
12 \cdot 3 \\
27 \cdot 6 \\
29 \cdot 6 \\
24 \cdot 8\end{array}$ & $\begin{array}{l}-19.6 \\
-19.9 \\
-32.3 \\
-30.9 \\
-15.8 \\
+18.9 \\
+7.6 \\
+19.2\end{array}$ & \begin{tabular}{|c|}
2 \\
5 \\
5 \\
6 \\
12 \\
no diuresis \\
no diuresis \\
no diuresis
\end{tabular} \\
\hline
\end{tabular}

to less than $\frac{1}{2}$ part in several cases, a decrease out of all proportion to the increase in urinary output. On four of the five occasions when a satisfactory diuresis occurred, marked reduction in the albuminuria was noted within 36 hours of stopping cortisone, and in the fifth case this fall occurred after 72 hours. The maximal diminution in urinary albumin concentration occurred on the fourth, fifth, eighth, ninth and eleventh days after cortisone respectively. In two cases (R.P. and A.P.) the albuminuria disappeared completely and has not reappeared after nine months. On the other three occasions the albuminuria recurred after 14, 26 and 56 days respectively.

Effects of Cortisone on Serum Proteins. It was intended to measure the total serum proteins before cortisone treatment, at the end of cortisone treatment and on several occasions thereafter but only in four cases was such a complete record obtained. During cortisone treatment the total proteins fell on three occasions and were unchanged in one, but on no occasion was the fall of great extent (Table 2). Four weeks after the end of treatment an appreciable rise had occurred in all

TABLE 2

TOTAL SERUM PROTEINS BEFORE, DURING AND AFTER CORTISONE TREATMENT

\begin{tabular}{|c|c|c|c|c|c|c|}
\hline Name & 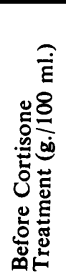 & 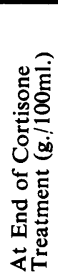 & 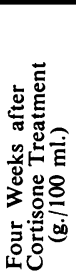 & 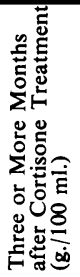 & 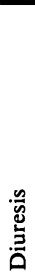 & 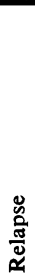 \\
\hline $\begin{array}{l}\text { R.P. } \\
\text { A.P. } \\
\text { J.N. } \\
\text { J.H. } \\
\text { J.H.* } \\
\text { C.Y. } \\
\text { F.M. } \\
\text { F.M.* }\end{array}$ & $\begin{array}{l}3 \cdot 72 \\
4 \cdot 14 \\
5 \cdot 17 \\
4 \cdot 29 \\
-\overline{8} \\
4 \cdot 80 \\
4 \cdot 65 \\
5 \cdot 71\end{array}$ & $\begin{array}{l}-\overline{8} \\
-70 \\
3 \cdot 41 \\
5 \cdot 12 \\
4 \cdot 82 \\
4 \cdot 56 \\
3 \cdot 44\end{array}$ & $\begin{array}{l}5 \cdot 02 \\
5 \cdot 34 \\
5 \cdot 24 \\
- \\
5 \cdot 62 \\
4 \cdot 29 \\
5 \cdot 42 \\
4 \cdot 84\end{array}$ & $\begin{array}{l}5 \cdot 52 \\
5 \cdot 92 \\
4 \cdot 64 \\
-7 \\
4 \cdot 56 \\
3 \cdot 72 \\
5 \cdot 71 \\
4 \cdot 10\end{array}$ & $\begin{array}{l}+ \\
+ \\
+ \\
+ \\
+ \\
0 \\
0 \\
0\end{array}$ & $\begin{array}{l}0 \\
0 \\
+ \\
+ \\
+ \\
- \\
-\end{array}$ \\
\hline
\end{tabular}


TABLE 3

ALBUMin AND GLOBULIN CONTENT OF SERUM BeFORE, DURING AND AFTER CORTISONE TREATMENT

\begin{tabular}{|c|c|c|c|c|c|c|c|c|c|c|}
\hline \multirow[b]{2}{*}{ Case } & \multicolumn{2}{|c|}{$\begin{array}{l}\text { Before Cortisone } \\
\text { Treatment }\end{array}$} & \multicolumn{2}{|c|}{$\begin{array}{l}\text { Immediately after } \\
\text { Cortisone Treatment }\end{array}$} & \multicolumn{2}{|c|}{$\begin{array}{l}\text { Four Weeks after } \\
\text { Cortisone Treatment }\end{array}$} & \multicolumn{2}{|c|}{$\begin{array}{l}\text { Three Months after } \\
\text { Cortisone Treatment }\end{array}$} & \multirow[b]{2}{*}{ Diuresis } & \multirow[b]{2}{*}{ Relapse } \\
\hline & $\begin{array}{r}\text { Albumir } \\
\text { (g. } p\end{array}$ & $\begin{array}{l}\text { lobulins } \\
\text { ml.) }\end{array}$ & $\begin{array}{l}\text { Albumin } \\
\text { (g. p }\end{array}$ & $\begin{array}{l}\text { lobulins } \\
\text { ml.) }\end{array}$ & $\underset{\text { (g. } p}{\text { Albumi }}$ & $\begin{array}{l}\text { lobulins } \\
\text { ml.) }\end{array}$ & $\underset{\text { (g. } p}{\text { Albumi }}$ & $\begin{array}{l}\text { lobulins } \\
\text { ml.) }\end{array}$ & & \\
\hline $\begin{array}{l}\text { R.P. } \\
\text { A.P. } \\
\text { J.N. } \\
\text { J.H. } \\
\text { J.H.* } \\
\text { C.Y. } \\
\text { F.M. } \\
\text { F.M.* }\end{array}$ & $\begin{array}{l}0.58 \\
0 \cdot 30 \\
0.31 \\
0.27 \\
-.15 \\
1 \cdot 15 \\
0.95 \\
0.93\end{array}$ & $\begin{array}{l}3 \cdot 12 \\
3 \cdot 82 \\
4 \cdot 84 \\
4 \cdot 01 \\
- \\
3 \cdot 63 \\
3 \cdot 66 \\
4 \cdot 75\end{array}$ & $\begin{array}{l}\overline{0} \cdot \overline{22} \\
\overline{0} \\
0 \cdot 21 \\
0.37 \\
\overline{0.45}\end{array}$ & $\begin{array}{l}3 \cdot 57 \\
-\overline{17} \\
4 \cdot 17 \\
4 \cdot 74 \\
\overline{2} \cdot 98\end{array}$ & $\begin{array}{c}2 \cdot 27 \\
2.85 \\
0.48 \\
- \\
2.46 \\
0.80 \\
0.50 \\
1 \cdot 17\end{array}$ & $\begin{array}{l}2 \cdot 75 \\
2 \cdot 49 \\
4 \cdot 76 \\
-7 \\
3 \cdot 13 \\
3 \cdot 50 \\
4 \cdot 92 \\
3 \cdot 68\end{array}$ & $\begin{array}{l}3.03 \\
5.05 \\
0.56 \\
-\overline{-} \\
0.56 \\
0.66 \\
0.93 \\
0.80\end{array}$ & $\begin{array}{l}2 \cdot 44 \\
0 \cdot 85 \\
4 \cdot 08 \\
- \\
3 \cdot 99 \\
3 \cdot 06 \\
4 \cdot 75 \\
3 \cdot 31\end{array}$ & $\begin{array}{l}+ \\
+ \\
+ \\
+ \\
+ \\
0 \\
0 \\
0\end{array}$ & $\begin{array}{l}0 \\
0 \\
+ \\
+ \\
+ \\
+ \\
-\end{array}$ \\
\hline
\end{tabular}

cases except one (C.Y.). The greatest rises occurred in R.P. $(1 \cdot 30 \mathrm{~g}$. per $100 \mathrm{ml}$.$) and A.P. (1 \cdot 20 \mathrm{~g}$. per $100 \mathrm{ml}$.) and these two are the patients in whom oedema and albuminuria have not recurred. On the other hand, F.M. in whom the total proteins had risen by $0.77 \mathrm{~g}$. per $100 \mathrm{ml}$., had a higher total protein level four weeks after cortisone than either R.P. or A.P. and yet his oedema was increasing. Three months after treatment R.P. and A.P. showed further increases in total serum protein content; but all the other cases except F.M. had returned to about their pre-treatment levels, with a return of oedema and massive albuminuria.

The various components of the serum protein were measured and these results are shown in Table 3. The $\alpha, \beta$ and $\gamma$ fractions of the globulin were estimated separately, but as no significant individual alteration was found the actual detailed figures are not shown.

It will be seen that in every case for which results were obtained the level of serum albumin was lower at the end of the cortisone treatment than before it. Where diuresis occurred, the albumin having first shown a fall, rose to a level far above the original. Indeed from the figures shown in the case of J.H.* one might have expected her to remain as free of oedema as R.P. and A.P. On the three occasions when no diuresis occurred the fall in the level of serum albumin during treatment was succeeded by a much smaller rise which only regained the original level in one case (F.M.*).

In all the patients who were later to have a diuresis, a marked fall occurred in the globulins of the serum some weeks after cortisone treatment: when diuresis did not occur the globulins were little altered. The fractionation shows clearly that the rise which occurred in the total serum protein level in A.P. and R.P. was produced by a very marked increase in albumin content which masked a fall in the globulins. In F.M. the reverse occurred, and the increase in his serum protein content derived from a rise in serum globulin, the serum albumin actually showing a slight fall. Thus the apparent paradox of contradictory clinical results in one of the cases having a marked rise in total serum proteins is explained.

The electrophoretic curves, obtained from these patients' sera, show clearly certain significant changes in the pattern of the proteins. The characteristic alteration in nephrosis is a marked reduction in the albumin and a large increase in the $\alpha$ and $\beta$ globulins. It should be pointed out, however, that this particular pattern is not specific for nephrosis but may be seen after any form of trauma such as burns, fractures, acute infections or artificially produced nephrosis (Teilum, Engbaek, Harboe and Simonsen, 1951). The effect of cortisone treatment on the serum proteins of three of our cases is shown graphically in Fig. 1. Case R.P. had a diuresis, followed by apparent cure, and her rapid and sustained rise in serum albumin content, coupled with a fall in the serum globulins, is evident. J.N. had a transient diuresis, reflected by a slight rise in albumin, which rapidly regressed to the usual nephrotic pattern. C.Y. had no diuresis and no significant alteration in her electrophoretic pattern following the cortisone therapy.

Having ascertained the quantity of each of the components of the serum proteins contained in a given volume of blood an attempt was then made to determine the total quantity of each protein in circulation. To this end the blood volume was estimated before and after treatment in four patients, two who responded to cortisone therapy and two who failed to respond. From these values and the known content of each protein fraction per unit volume the total quantities in circulation were calculated (Table 4). It will be seen that the marked drop in blood volume which occurred in the cases R.P. and J.N. who responded to cortisone tended to mask the absolute fall in globulin (when measured per unit volume), whilst the actual rise in the absolute level of albumin was, in the same way, exaggerated. Nevertheless, the final level of 
TABLE 4

EFFECT ON PLASMA VOLUME AND TOTAL CIRCULATING PROTEIN OF CORTISONE TREATMENT

\begin{tabular}{|c|c|c|c|c|c|c|c|c|c|c|}
\hline & R.1 & & J.I & & & C.Y. & & & F.M.* & \\
\hline & $\begin{array}{c}\text { Before } \\
\text { Cortisone } \\
\text { Treatment }\end{array}$ & $\begin{array}{l}\text { After } \\
\text { Diuresis }\end{array}$ & $\begin{array}{c}\text { Before } \\
\text { Cortisone } \\
\text { Treatment }\end{array}$ & $\begin{array}{l}\text { After } \\
\text { Diuresis }\end{array}$ & $\begin{array}{c}\text { Before } \\
\text { Cortisone } \\
\text { Treatment }\end{array}$ & $\begin{array}{c}\text { During } \\
\text { Cortisone } \\
\text { Treatment }\end{array}$ & \begin{tabular}{|c|} 
Two \\
Weeks \\
after \\
Cortisone \\
Treatment \\
\end{tabular} & $\begin{array}{c}\text { Before } \\
\text { Cortisone } \\
\text { Treatment }\end{array}$ & $\begin{array}{c}\text { During } \\
\text { Cortisone } \\
\text { Treatment }\end{array}$ & $\begin{array}{c}\text { Two } \\
\text { Weeks } \\
\text { after } \\
\text { Cortisone } \\
\text { Treatment }\end{array}$ \\
\hline Plasma volume (ml.) & 643 & 591 & 1,360 & 1,042 & 908 & 979 & 930 & 1,069 & 1,086 & 875 \\
\hline $\begin{array}{l}\text { Total circulating } \\
\text { protein }(\mathrm{g} .)\end{array}$ & $24 \cdot 6$ & $30 \cdot 3$ & $72 \cdot 9$ & $57 \cdot 4$ & $44 \cdot 3$ & $50 \cdot 8$ & $36 \cdot 8$ & $62 \cdot 9$ & $40 \cdot 1$ & $38 \cdot 8$ \\
\hline $\begin{array}{l}\text { Total circulating } \\
\text { albumin (g.) }\end{array}$ & $3 \cdot 8$ & $13 \cdot 4$ & $4 \cdot 3$ & $5 \cdot 0$ & $10 \cdot 4$ & $4 \cdot 7$ & $6 \cdot 1$ & $9 \cdot 6$ & $5 \cdot 5$ & $6 \cdot 9$ \\
\hline $\begin{array}{l}\text { Total circulating } a \\
\quad \text { and } \beta \text { globulin (g.) }\end{array}$ & $17 \cdot 5$ & $13 \cdot 3$ & $60 \cdot 2$ & $40 \cdot 2$ & $27 \cdot 3$ & $35 \cdot 4$ & $24 \cdot 2$ & $42 \cdot 8$ & $25 \cdot 9$ & $25 \cdot 2$ \\
\hline $\begin{array}{l}\text { Total circulating } \\
\gamma \text { globulin (g.) }\end{array}$ & $2 \cdot 6$ & $2 \cdot 9$ & $5 \cdot 8$ & $9 \cdot 4$ & $5 \cdot 7$ & $7 \cdot 1$ & $4 \cdot 4$ & $8 \cdot 6$ & $4 \cdot 3$ & $2 \cdot 7$ \\
\hline $\begin{array}{l}\text { Total circulating } \\
\text { fibrinogen (g.) }\end{array}$ & 0.7 & 0.7 & $2 \cdot 6$ & $2 \cdot 8$ & 0.9 & $3 \cdot 6$ & $2 \cdot 1$ & $1 \cdot 9$ & $4 \cdot 4$ & $4 \cdot 0$ \\
\hline
\end{tabular}

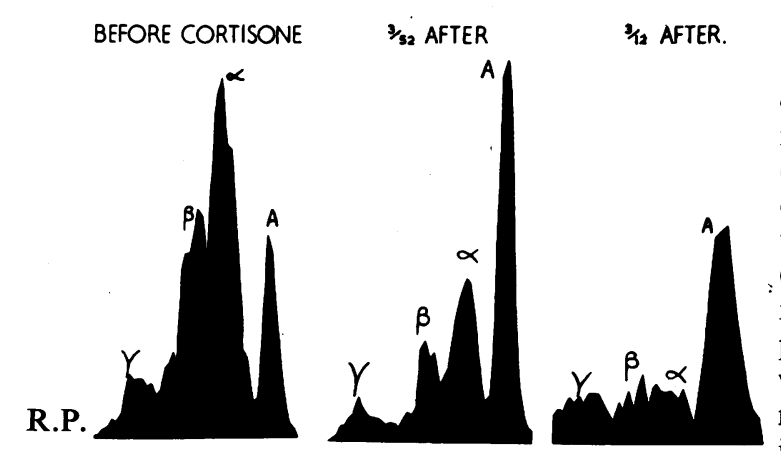

total circulating albumin in R.P. amounted to $13.4 \mathrm{~g}$., the original level being only $3.8 \mathrm{~g}$. This case responded by a diuresis and the disease has not recurred. Unfortunately the blood volume determinations were not completed on A.P., the other case in which oedema did not recur. In the two patients who failed to respond to treatment (C.Y. and F.M.*) there is shown to be a marked fall in the total circulating albumin after treatment, partly masked in F.M.* by the fall in blood volume which took place. Further, it is striking that a marked rise in total circulating fibrinogen occurred in C.Y. and F.M.*, two cases in which diuresis did not occur.

These observations appear to justify a few comments concerning the relationship of the low serum protein level to the albuminuria and the oedema in nephrosis. Several current medical textbooks still suggest that oedema in nephrosis is due to low serum protein levels caused by renal loss of albumin. Such a suggestion appears more plausible when it is considered that the protein loss in the urine consists almost entirely of albumin, that the fall in serum proteins is brought about almost entirely by a fall in albumin, and that albumin has a greater effect on the osmotic pressure of the serum than globulin. That a fall in the level of albumin in the plasma may result from albuminuria is by no means proven; but, in any case, it is improbable that the loss in the urine is sufficient to account for the sustained low concentration in the blood, if production by the liver were continuing at a normal rate. Barnett, Forman and Lauson (1952) have pointed out that the amount of albumin lost in the urine of nephrotic patients is directly proportional to the level of 
plasma albumin. It appears to us that the low level of plasma albumin in nephrosis may be in the nature of a protective mechanism intended to minimize the loss of albumin in the urine and, incidentally, lowering the osmotic pressure of the plasma.

These facts are well demonstrated by the case of J.N. after cortisone treatment when, although oedema and albuminuria had both disappeared, the total circulating protein in the blood had actually fallen from $72.9 \mathrm{~g}$. to $57.4 \mathrm{~g}$. and the total circulating albumin had risen by only $0.7 \mathrm{~g}$. (Table 4). At this time the concentration of the total proteins in the serum had risen only from $5 \cdot 17$ to $5 \cdot 24 \mathrm{~g}$. per $100 \mathrm{ml}$. (Table 2) and of albumin from 0.31 to $0.48 \mathrm{~g}$. per $100 \mathrm{ml}$. (Table 3). This evidence that the oedema and albuminuria may disappear without any material alteration in albumin content of the serum is very strong. Furthermore, in J.N. the failure of the serum albumin content to rise despite the cessation of renal loss strongly suggests that some factor is inhibiting the production of albumin.

Plasma Cholesterol in Relation to Treatment. The values obtained for plasma cholesterol levels before, during and after treatment are shown in Table 5. During the giving of cortisone the

\section{TABLE 5}

PLASMa CHOLESTEROL IN RELATION TO CORTISONE TREATMENT

\begin{tabular}{|c|c|c|c|c|c|c|}
\hline Case & 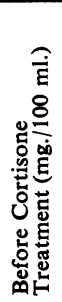 & 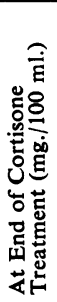 & 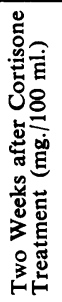 & 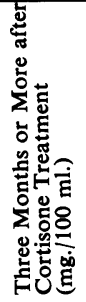 & 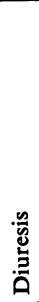 & 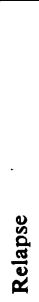 \\
\hline $\begin{array}{l}\text { R.P. } \\
\text { A.P. } \\
\text { J.N. } \\
\text { J.H. } \\
\text { J.H.** } \\
\text { C.Y. } \\
\text { F.M. } \\
\text { F.M.* }\end{array}$ & $\begin{array}{l}430 \\
620 \\
580 \\
527 \\
554 \\
368 \\
496 \\
303\end{array}$ & $\begin{array}{l}-\overline{239} \\
\overline{446} \\
484 \\
320 \\
\overline{302}\end{array}$ & $\begin{array}{l}350 \\
444 \\
528 \\
462 \\
472 \\
272 \\
430 \\
204\end{array}$ & $\begin{array}{l}104 \\
132 \\
566 \\
553 \\
\overline{486} \\
\overline{295}\end{array}$ & $\begin{array}{l}+ \\
+ \\
+ \\
+ \\
+ \\
0 \\
0 \\
0\end{array}$ & $\begin{array}{l}0 \\
0 \\
+ \\
+ \\
+ \\
+ \\
-\end{array}$ \\
\hline
\end{tabular}

cholesterol content of the plasma fell on four occasions and remained unchanged in another. A fortnight later the levels showed a tendency to rise slightly: indeed, in one of the two cases in which there was no recurrence of the oedema it showed an appreciable rise from 239 to $444 \mathrm{mg}$. per $100 \mathrm{ml}$. only to fall to normal levels three months later. In those patients in whom relapse occurred and in those who did not show a diuresis the level of plasma cholesterol rose to the original high levels within one month after treatment and remained elevated. The two cases with clinical cure (A.P. and R.P.) had normal levels of plasma cholesterol three months after treatment.

\section{Discussion}

In the natural course of nephrosis it is well known that spontaneous remission or recovery may occasionally take place. However, the occurrence of diuresis on five of eight occasions after cortisone treatment was stopped is too frequent to be fortuitous. It might be asked whether such diuresis would not have taken place had the hormone treatment been continued. The work of Sprague, Power, Mason, Albert, Mathieson, Hench, Kendall, Slocumb and Polley (1950) on the effects of cortisone treatment on the water, sodium and chloride balance of the human subject strongly suggested that sudden withdrawal is essential, if diuresis is to be produced. Sprague et al. showed that depression of endogenous cortisone output existed for several days after cortisone therapy was discontinued. This depression was demonstrated by a diminution of 17-ketosteroid excretion, of the eosinopenic response to injected A.C.T.H. and by the general loss of well-being in the patient. McIntosh and Holmes (1951) confirmed this work and claimed that pituitary A.C.T.H. output was also diminished. These physiological studies were confirmed clinically by Luetscher et al. (1951) who found that diuresis occurred after cortisone treatment was stopped in 13 of the 18 cases of nephrosis which they treated with this hormone.

What rôle the 11-oxysteroid group of adrenal hormones plays in the production of nephrosis is difficult to ascertain. It has been shown experimentally that existing albuminuria or nephritis is aggravated and altered by treatment with these hormones. Furthermore, Metcoff, Rance and Nakasone (1951) have shown that hormone treatment of nephrosis (producing adrenal depression) promotes a rejection of sodium by the renal tubular cells. This suggests the possibility that the initial fault may lie in the retention of sodium by these cells, an action potentiated by cortisone and other adrenal hormones. Why excessive action of these hormones should exist, or indeed whether it does exist in nephrotic subjects is not apparent.

Spontaneous remissions often follow acute infections by bacterial or virus diseases. Barness, Moll and Janeway (1950) record that 297 infections occurred in their 161 cases of nephrosis and diuresis followed, one to 15 days after the infection, on 75 occasions. So striking is this sequence of infection followed by diuresis that it has been 
suggested that nephrotic patients should be deliberately infected with measles, the most consistent precursor of diuresis, in an endeavour to promote a remission (Blumberg and Cassady, 1947). It would seem that this type of diuresis following infection is so similar to that following the stopping of cortisone therapy that the mechanism must be similar. It is suggested that infection stimulates the endogenous production of 11-oxysteroid hormones via the pituitary-adrenal axis, that the diuresis coincides with a sudden drop in circulating hormone and that this relative 'cortisone withdrawal' results in sodium loss and diuresis with diminution of albuminuria.

Our data show that while diuresis followed cortisone therapy in four of six cases of nephrosis treated, relapse occurred in two of these cases in which it would appear that some toxic or metabolic factor has continued to act on the renal tubules and overcome the beneficial results of treatment. The two patients who failed to respond to treatment remain enigmata: that their renal function was not grossly impaired was shown by the normal urea concentration of which their kidneys were capable. The blood proteins and albuminuria appeared to react initially in a fashion similar to the successful cases, but the response must have been incomplete or insufficient in some unrecognized way to overcome the disease process.

The main value of cortisone treatment appears to lie in the ability of the hormone to promote diuresis in a larger proportion of cases than any other treatment (except perhaps A.C.T.H.). Thus cortisone is a valuable therapeutic measure as well as a useful research weapon in the investigation of this fascinating condition.

\section{Summary}

Six cases of nephrosis were treated with large doses of cortisone, the treatment being stopped abruptly. In four of the cases a diuresis with loss of oedema and albuminuria followed the termination of therapy. Two of these cases have had no recurrence of oedema or albuminuria and their blood chemistry has remained normal.

It is suggested that the oedema in nephrosis is not primarily due to a diminution in the plasma proteins. Furthermore the low level of blood proteins is not satisfactorily explained by loss of albumin in the urine. It appears probable that there is a reduced synthesis of albumin by nephrotic patients.

Cortisone is considered to be a useful method of provoking diuresis in nephrotic patients.

We are glad of the opportunity to acknowledge our indebtedness to Professor Stanley Graham for his constructive advice and criticism and to both Professor Graham and Dr. J. H. Hutchison for allowing us to study cases in their wards.

\section{CASE REPORTS}

Case 1. R.P. was a girl aged 20 months. She was healthy until September, 1950, when generalized oedema and albuminuria developed and she was admitted to hospital. Her weight was then $11.65 \mathrm{~kg}$. and her urine contained $12 \mathrm{~g}$. of albumin per litre and many hyaline and granular casts and a few red blood cells. Her blood chemistry at this time gave a total serum protein content of $4.75 \mathrm{~g}$. per $100 \mathrm{ml}$. (1.94 g. albumin and $2 \cdot 63 \mathrm{~g}$. globulin). The plasma cholesterol was $353 \mathrm{mg}$. per $100 \mathrm{ml}$. The oedema gradually receded until on December 4 her weight was $9.3 \mathrm{~kg}$., but the heavy albuminuria persisted and pitting was always present in the ankle region despite treatment by a low-sodium diet and various diuretics. She was discharged in April, 1951, still with oedema and albuminuria.

The patient was readmitted in July, 1951, with gross oedema and ascites. Her blood pressure was 110/70 $\mathrm{mm}$. of mercury and her weight $13.7 \mathrm{~kg}$. The urine contained $24 \mathrm{~g}$. of albumin per litre, many hyaline and granular casts, but no red blood cells. As her weight remained high on the low-sodium diet a five-day course of cortisone, $100 \mathrm{mg}$. daily, was given. Two days after the hormone was stopped her weight dropped rapidly and the albuminuria almost disappeared. By August she was completely free of oedema and albuminuria and weighed $11.86 \mathrm{~kg}$. She was dismissed in September. She has remained free of oedema and albuminuria; she has been seen periodically since, and in May, 1952, was in excellent health with no abnormal findings in her urine or blood chemistry.

Case 2. A.P. was a girl aged 17 months. She was well until aged 16 months when generalized oedema appeared. She was admitted to hospital two weeks later in July, 1951.

She was a well-developed child with marked oedema of the limbs, lumbo-sacral region and face. A moderate degree of ascites was present. No abnormality of any other system was detected. Her haemoglobin was $15.5 \mathrm{~g}$. per $100 \mathrm{ml}$. blood and her blood pressure $110 / 70 \mathrm{~mm}$. of mercury. The urine contained $16 \mathrm{~g}$. of protein per litre and many hyaline and granular casts. She was given the low-sodium diet and, as her weight and oedema continued to increase, a five-day course of $100 \mathrm{mg}$. cortisone intramuscularly was started. Five days after the hormone treatment ceased the albuminuria decreased and a brisk diuresis occurred. Ten days after treatment she was free of oedema and albuminuria and her weight was stabilized at $10.7 \mathrm{~kg}$. She was sent home in August, 1951, and remained very well and free of oedema and albuminuria. In March, 1952, her blood was found to have a normal serum protein and cholesterol content. She was last seen in May, 1952, when albuminuria and oedema were absent.

Case 3. J.N. was a boy, aged $6 \frac{1}{2}$ years. His previous health had been good, apart from an attack of bronchitis in January, 1951. In April, 1951, he was noted to have developed oedema and was admitted to hospital. 
Examination confirmed the presence of oedema and ascites and of albuminuria amounting to $16 \mathrm{~g}$. per litre. The urine contained a number of hyaline and granular casts but no red blood cells. The blood pressure was $90 / 50 \mathrm{~mm}$. of mercury. Despite the low-sodium diet the oedema continued to increase and a five-day course of $100 \mathrm{mg}$. cortisone twice daily was started. Next day a small haematemesis occurred and four days later a low-grade skin infection in the lumbar region appeared and was controlled by penicillin therapy. Five days after cortisone was stopped diuresis occurred and the degree of albuminuria markedly lessened. The albuminuria gradually returned but the boy remained practically free of oedema until July, 1951, when the oedema, ascites and gross albuminuria returned. $\mathrm{He}$ was subsequently treated with cation exchange resins and A.C.T.H., both of which produced temporary remissions to be followed once more by oedema and albuminuria.

Case 4. J.H. was a girl, aged $3 \frac{1}{4}$ years. She was healthy at birth and had developed normally. In February, 1951, she developed bronchitis and three weeks later the face, arms and legs became swollen: her urine was noted to be scanty and she was admitted to hospital.

Examination confirmed the presence of marked oedema, ascites and an albuminuria amounting to $18 \mathrm{~g}$. per litre. Some hyaline casts were present in the urine but no red blood cells. Her blood pressure was 100/70 $\mathrm{mm}$. of mercury and no other abnormality was detected on clinical examination. She was put on the lowsodium diet but as the oedema continued to increase, a five-day course of cortisone ( $225 \mathrm{mg}$. per day) was given intramuscularly. The albuminuria decreased three days after the hormone treatment ceased and her weight fell markedly. Two weeks later her weight began to rise and oedema and albuminuria became more marked.

A second similar course of cortisone was started in April, 1951. Twelve days after the hormone was stopped diuresis again occurred, the albuminuria having markedly decreased 10 days before. The child remained comparatively free of oedema but the albuminuria later returned and after being sent home she became oedematous again. Later she developed peritonitis and died on July 21, 1951, despite vigorous antibiotic therapy.

Case 5. C.Y. was a girl, aged 7 years. She had grown and developed normally until July, 1951, when she complained of abdominal pain and a sore throat. Four weeks later the eyes became swollen, she became listless and developed anorexia. This gradually receded, then on September 5 the eyes became very swollen and the abdomen enlarged. She was admitted in September, 1951.

She was a well-nourished child with marked oedema of face, limbs and trunk. Ascites was present. Her blood pressure was $110 / 80 \mathrm{~mm}$. of mercury. Her urine contained $18 \mathrm{~g}$. of protein per litre and granular and hyaline casts but no red blood cells.

She was put on a low-sodium diet, but the oedema and ascites slowly increased and a five-day course of cortisone (100 mg. b.i.d.) was given. Her weight, oedema and ascites became progressively worse both on treatment and afterwards. The proteinuria lessened three days after the cortisone was stopped. A urea concentration test showed a concentration of $3.29 \mathrm{~g}$. per $100 \mathrm{ml}$. urine on November 9, 1951, proving that renal function still was good. The blood chemistry analysis was repeated in January, 1952, in preparation for treatment with A.C.T.H. but the next day she developed pneumonia which persisted until January 9. Five days later a very marked diuresis with lessening of albuminuria occurred and she lost $6 \mathrm{~kg}$. in weight in eight days. The oedema and ascites completely disappeared and have not recurred but albuminuria was still marked on May 26, 1952.

Case 6. F.M. was a boy aged $5 \frac{1}{2}$ years when admitted on July 22, 1951. He had been well until June, 1951, when swelling of the eyelids was noted. Oedema of the limbs and of the sacral region followed and a moderate degree of ascites was detected. No abnormality of the cardiovascular, respiratory or alimentary system was noted. The blood pressure was $115 / 65 \mathrm{~mm}$. of mercury. The urine contained $18 \mathrm{~g}$. of protein per litre, and many hyaline casts and an occasional red blood cell were present. Despite the low-sodium diet, oedema and ascites increased steadily and a five-day course of $\mathbf{1 5 0}$ mg. cortisone intramuscularly was started. No diuresis occurred but the albuminuria fell to $4 \mathrm{~g}$. per litre for several days after treatment. A second course of 300 $\mathrm{mg}$. cortisone intramuscularly was started in October. Again the albuminuria lessened after treatment but the oedema and ascites continued to increase. The blood pressure was not elevated and urea was concentrated to $2 \cdot 28 \mathrm{~g}$. urea per $100 \mathrm{ml}$ : of urine.

In November, 1951, 9 litres of chylous fluid were removed by paracentesis abdominis, and the boy's weight, which had been $30 \mathrm{~kg}$. before paracentesis, steadily fell thereafter to $17 \cdot 8 \mathrm{~kg}$. The oedema and albuminuria still persist eight months later.

\section{REFERENCES} Addis, T., Marmorston, J., Goodman, H. C., Sellers, A. L. and

Barness, L. A., Moll, G. H. and Janeway, C. A. (1950). Pediatrics, $5,486$.

Barnett, H. L., Forman, C. W. and Lauson, H. D. (1952). Advanc. Pediat., 5, 53.

Blumberg, R., W. and Cassady, H. A. (1947). Amer. J. Dis. Child., 73, 151 .

Chinard, F. P. and Eder, H. A. (1948). J. exp. Med., 87, 473.

Cremer, H. D. and Tiselius, A. (1950). Biochem. Z., 320, 273.

Kendali, E. C. (1951). Brit. med. J., 2, 1295.

Levitt, M. F. and Bader, M. E. (195i), J. clin. Invest., 30, 655.

Luetscher, J. A. and Deming, Q. B. (1950). Ibid., 29, 1576.

Luetscher, And Johnson, B. B. (195i). Ibid., 30, 658.

McIntosh, H. W. and Holmes, C. B. (1951). Lancet, 2, 1061.

Metcoff, J., Rance, C. P. and Nakasone, N. (1951). J. clin. Invest.,

30, 661.
Sprague, R. G., Power, M. H., Mason, H. L., Albert, A., Mathieson, D. R., Hench, P. S., Kendall, E. C., Slocumb, C. H. and Polley, H. F. (1950). Arch. intern. Med., 85, 199.

Teilum, G., Éngbaek, H. C., Harboe, N. and Simonsen, M. (1951). J. clin. Path., 4, 301.

\section{ADDENDUM}

Since this paper was written three more cases have been successfully treated, in one of which cortisone was given orally. 